\title{
Histopathological Evaluation of LAG-3, TIM-3 AND CD38 Levels in Meningiomas
}

\author{
(1) Uzay Erdoğan ${ }^{1}$, (1) Ozan Haşimoğlu², (1) Ceyhan Oflezer ${ }^{3}$, (1) Osman Tanrıverdi², \\ (D) Canan Tanık ${ }^{4}$, (D) Ömür Günald²
}

\author{
${ }^{1}$ Istanbul Bakırköy Prof. Dr. Mazhar Osman Mental Health and Neurological Diseases Training and Research \\ Hospital, Clinic of Neurosurgery, İstanbul, Turkey \\ 2University of Health Sciences Turkey, Başakşehir Çam and Sakura City Hospital, Clinic of Neurosurgery, İstanbul, \\ Turkey \\ ${ }^{3}$ Istanbul Bakırköy Prof. Dr. Mazhar Osman Mental Health and Neurological Diseases Training and Research \\ Hospital, Clinic of Anesthesiology and Reanimation, İstanbul, Turkey \\ 4University of Health Sciences Turkey, Şişli Hamidiye Etfal Training and Research Hospital, Clinic of Pathology, \\ İstanbul, Turkey
}

\section{What is known on this subject?}

Immune checkpoint molecules (ICM) regulate the immune system's response to different antigens.

\section{What this study adds?}

The relationship between meningiomas of different histopathological grades and ICM levels.

\section{ABSTRACT}

Objective: Meningiomas are the most common primary intracranial tumors in adults that account for $36 \%$ of primary tumors. Treatment options other than surgery and radiotherapy are necessary for meningioma. Immune checkpoint molecules (ICM) are modulators that regulate the proper response of the immune system. Lymphocyte activation gene-3 (LAG-3), T-cell immunoglobulin and mucin domain containing-3 (TIM-3), and the cluster of differentiation 38 (CD38) are known ICMs. This study hypothesized the relationship between meningiomas of different histopathological grades and the levels of these three ICMs. Additionally, the therapeutic potential of these molecules was investigated.

Material and Methods: This study re-evaluated 25 specimens diagnosed as meningioma. Tissues are classified according to LAG-3, TIM-3, and CD38 levels. Age, gender, surgery date, tumor type, and subtype, histopathologically malignant grade, radiological tumor size, and presence of edema were recorded in all patients. All data were statistically compared.

Results: This study included the specimens of 25 patients, of whom 9 were males and 16 were females. LAG-3 and CD38 levels were significantly higher in tumors bigger than $6 \mathrm{~cm}$.

Conclusion: This study is the first to investigate LAG-3, TIM-3, and CD38 levels in meningiomas and found a significant correlation between LAG-3 levels and meningioma size. No significant correlation was found with other data. However, the number of patients in our study was insufficient. Therefore, larger patient groups may yield more significant results.

Keywords: Immune, checkpoint, histopathology, meningioma, molecules

Address for Correspondence: Ozan Haşimoğlu MD, University of Health Sciences Turkey, Başakşehir Çam and Sakura City Hospital Clinic of Anesthesiology and Reanimation, İstanbul, Turkey

Phone: +90 5078727242 E-mail: ozanhasim@hotmail.com ORCID ID: orcid.org/0000-0003-1394-5188 Received: 18.06.2021 Accepted: 27.08.2021

(C) Copyright 2021 by the Cam \& Sakura Medical Journal published by Galenos Publishing House. 


\section{Introduction}

Meningiomas are the most common primary intracranial tumors in adults that account for $36 \%$ of primary tumors (1). It is classified as grade 1, 2, and 3 according to histopathological features $(2,3)$. Surgical resection is usually adequate in grade 1 meningiomas. However, the mean progression-free survival is 7 years in grade 2 tumors (atypical meningioma) and $<3$ years in grade 3 tumors (malignant meningioma). Of all meningiomas, $25-30 \%$ are grade 2 and $3 \%$ are grade 3 (3). Adjuvant radiotherapy is applied in these meningiomas; however, recurrence is often unavoidable (4), and treatment options other than surgery and radiotherapy are limited (5). Therefore, new and effective treatment methods are required.

Recently, the potential of immune checkpoint molecules (ICM) has been remarkable in meningioma treatment (2). ICM regulates the immune system's proper response to different antigens. The T-cell response is inhibited or stimulated by different molecules. Thus, the response of T-cells is regulated by a secondary signal after antigen recognition (6). Cancer cells use this way to evade the immune system. Tumors suppress the immune response by stimulating inhibitory ICMs and creating immune tolerance. Therefore, ICM modulation is considered a target in cancer immunotherapy for tumor activity suppression. These molecules include lymphocyte activation gene-3 (LAG-3), T-cell immunoglobulin and mucin domain containing-3 (TIM-3), and the cluster of differentiation 38 (CD38) (7). This study mainly hypothesized the relationship between meningiomas of different histopathological grades and the levels of these three ICMs. Additionally, the therapeutic potential of these molecules was investigated.

\section{Material and Methods}

This study was prospectively conducted after the approval decision of University of Health Sciences Turkey, Bakırköy Dr. Sadi Konuk Training and Research Hospital Local Ethics Committee, dated 08.01.2018 and numbered 2018-01-07.

Tissue samples obtained from patients who were operated on for brain tumors in our center were used. The samples were fixed in paraffin. Patients with an adequate amount of stored tumor tissue that are histopathologically diagnosed as meningioma, with all ages and genders, who were on operated for the first time for the tumor, and did not receive chemotherapy or radiotherapy for the operated tumor were included in the study. Patients with different or suspicious tumor diagnoses were excluded from the study. Age, gender, surgery date, tumor type and subtype, histopathologically malignancy grade, radiological tumor size (8), and presence of edema were recorded in all patients.

\section{Histopathological Examination}

This study used meningioma tissue specimens that are obtained from a single center. Formalin-fixed and paraffinembedded sections ( $4 \mu \mathrm{m}$ ) from the samples were used for immunohistochemistry (IHC) staining. Paraffin-embedded tissue sections were baked in a drying oven at $60^{\circ} \mathrm{C}$ for $1 \mathrm{~h}$. Heatmediated antigen retrieval was performed on LAG-3 slides. All slides were labeled and placed in a Benchmark XT system (Ventana Medical Systems, Tucson, AZ). Histopathological sections of typical and atypical meningiomas are in Figures $1 \mathrm{~A}$ and B (Figure 1). After the slides had been treated with standard cell conditioning 1 solution for $60 \mathrm{~min}$, primary antibody cell signaling LAG-3 [DANVERS MA-USA CST 15372S (KLON D2G40) 1/100, cell signaling TIM-3 KLONd5d5r (DANVERS MA -USA CST 45208S) 1/200, and CD38 cellmarque clone (SP149) ROCKLIN -CA-USA 1/100 dilution was applied, and the slides were incubated at $37^{\circ} \mathrm{C}$ for $1 \mathrm{~h}$. An ultra view universal DAB detection and amplification kit (ROCHE, Ventana Tuscon Medical Systems] was used. Slides were counterstained with hematoxylin for $4 \mathrm{~min}$ and post counterstained with a bluing agent for $4 \mathrm{~min}$. Slides were washed and then dehydrated in $70-100 \%$ reagent alcohol baths and then in xylene baths before coverslip application. The human normal tonsil was used as the positive control for LAG-3.

\section{Histopathological Analysis}

All IHC results were independently reviewed by a pathologist who was blinded from the clinical data. It was expressed in the cytoplasm of the lymphocytes with brown

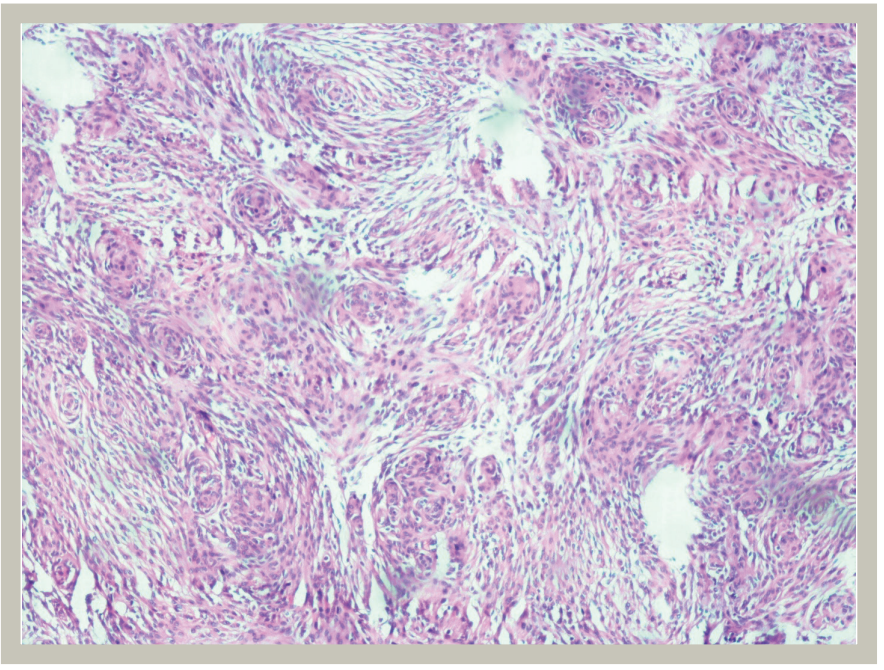

Figure 1A. Grade 1 meningothelial meningioma consisting of atypical meningothelial cells forming whorl structures (HEX100) 
color. The number of lymphocytes was calculated in the microscope's field of vision on hematoxylin-stained sections, as described. Five randomly especial perivascular spaceselected high-power fields $(400 \times)$ were averaged in each case to calculate the positive cell percentage. LAG-3, TIM-3, and CD38 tumor-infiltrating lymphocytes (TILS) were evaluated in a tumor. The infiltrating intensity of TILs was assessed with a semiquantitative score from $1+$ to $3+$, with a score of $1+$ that indicate a low TIL percentage (1-3 cell), $2+$ a moderate percentage (3-6 cell), and 3+ a marked increased percentage (6 cell up) (Table 1) (9). The TILs were composed of mononuclear cells, including lymphocytes, macrophages, and plasma cells (Figure 2, 3, 4).

\section{Statistical Analysis}

Parametric tests were used without normality tests due to compliance with the Central Limit Theorem (10). Data analyses used mean and standard deviation, minimum and maximum values of features, and frequency and percentage values to define the categorical variables. The chi-square test statistic was used to evaluate the relationship between categorical descriptive statistics in meningioma LAG-3, TIM3 , and CD38 parameters. The statistical significance level of data was taken as $p<0.05$. The www.e-picos.com New York

Table 1. Grading criteria according to LAG-3, TIM-3, CD38 levels

\begin{tabular}{llll} 
& $\begin{array}{l}\text { Grade 1 } \\
\text { (low) }\end{array}$ & $\begin{array}{l}\text { Grade 2 } \\
\text { (moderate) }\end{array}$ & $\begin{array}{l}\text { Grade 3 } \\
\text { (increase) }\end{array}$ \\
\hline TILs & $1-3$ & $4-6$ & $6+$
\end{tabular}

LAG-3: Lymphocyte activation gene-3, TIM-3: T-cell immunoglobulin and mucin domain containing-3, CD38: Cluster of differentiation 38, TILs: Tumor-infiltrating lymphocytes

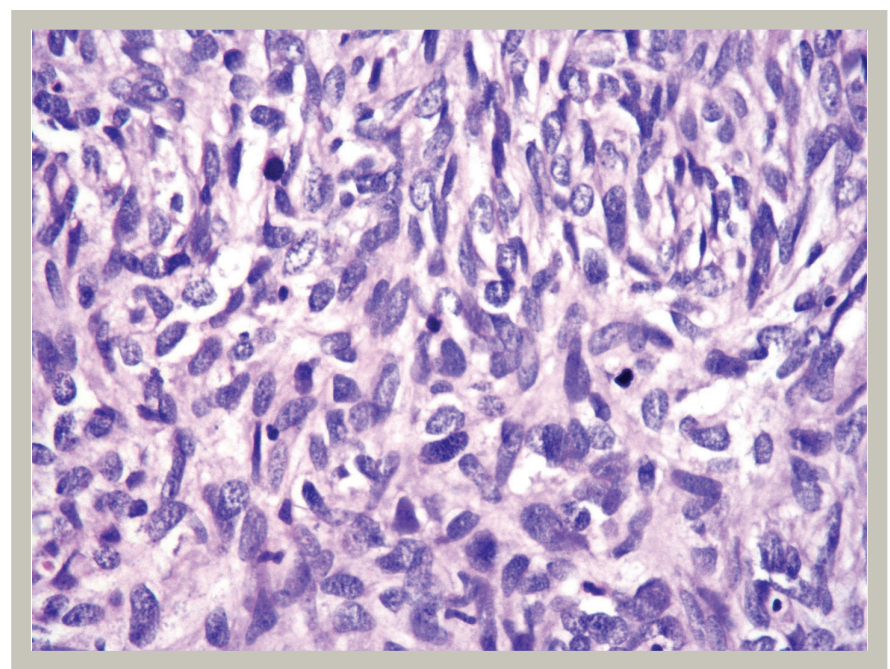

Figure 1B. Grade 2 atypical meningioma with atypical mitoses (HEX200) software and MedCalc statistical package program were used for data evaluation.

\section{Results}

This study included specimens of 25 patients, of whom 9 were males and 16 were females. According to the lesion location, six were frontal, six were occipital, six were parietal, and seven were in the temporal lobe. No significant difference was found between the location and LAG-3, TIM-3, and CD38 levels. According to histopathological tumor subtypes, four atypical, 5 fibrosis, five transitional, 4 meningeal, and seven anaplastic types were determined. No significant difference was found between meningioma subtypes and LAG-3, TIM-

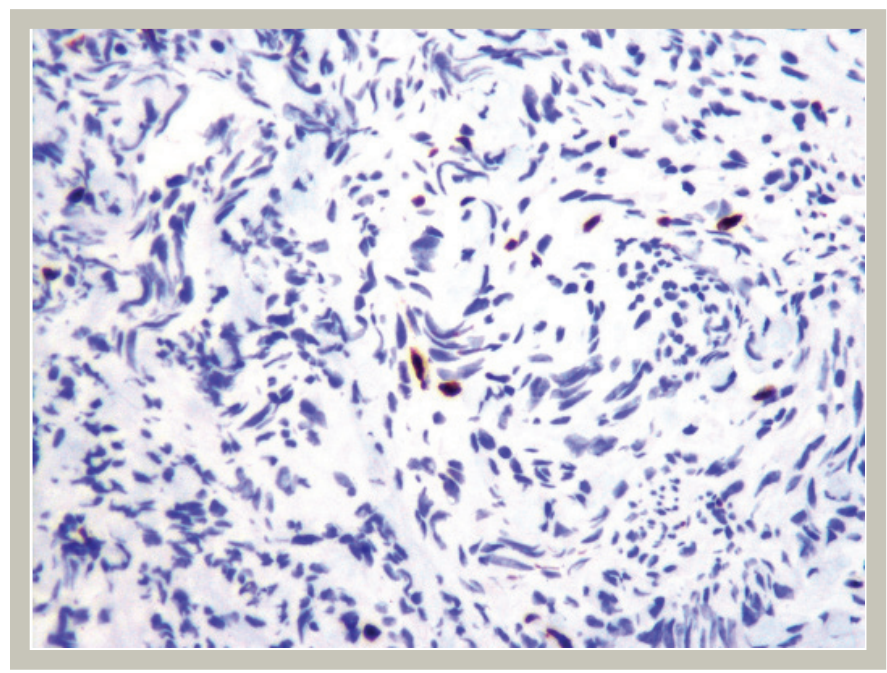

Figure 2A. LAG-3 grade 1, sparse cell collection (LAG-3X400) LAG-3: Lymphocyte activation gene-3

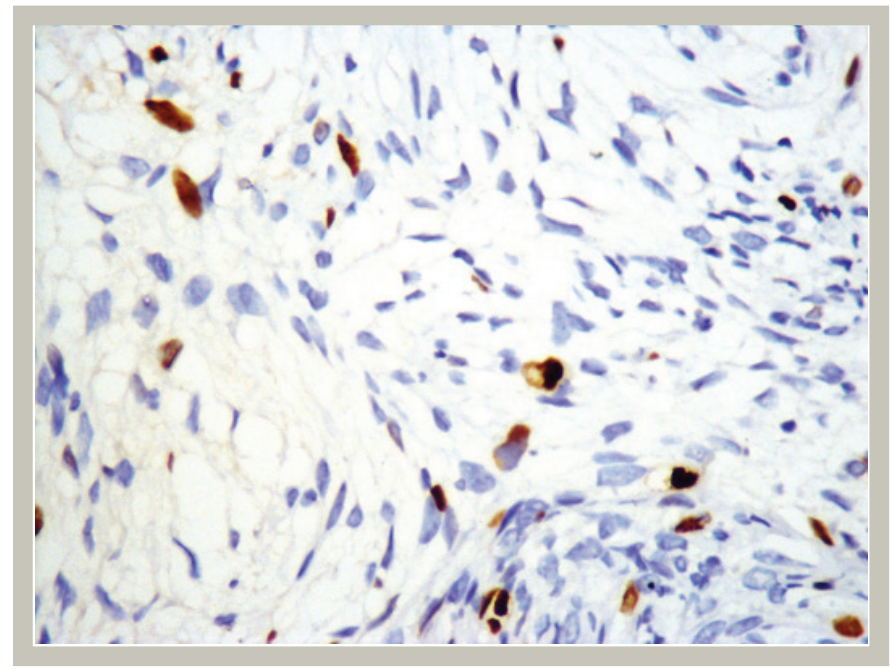

Figure 2B. LAG-3 grade 3 in the hotspot area (LAG-3X400)

LAG-3: Lymphocyte activation gene-3 
3, and CD38 levels. The number of specimens according to tumor size revealed that ten were $<3 \mathrm{~cm}$, 9 were $3-6 \mathrm{~cm}$, and 6 were $>6 \mathrm{~cm}$. LAG-3 and CD38 levels were significantly higher in tumors that are $>6 \mathrm{~cm}$ in size $(p<0.01)$. No significant difference was found between parenchymal invasion, bone invasion, and edema severity, and LAG-3, TIM-3, and CD38 levels. All findings are summarized in Table 2, 3, 4.

\section{Discussion}

Meningiomas are the most common primary intracranial tumors in adults (1). Treatment options are limited without surgery and radiotherapy (5). Therefore, studies are conducted for new and alternative treatments (2). Recently, a lot of

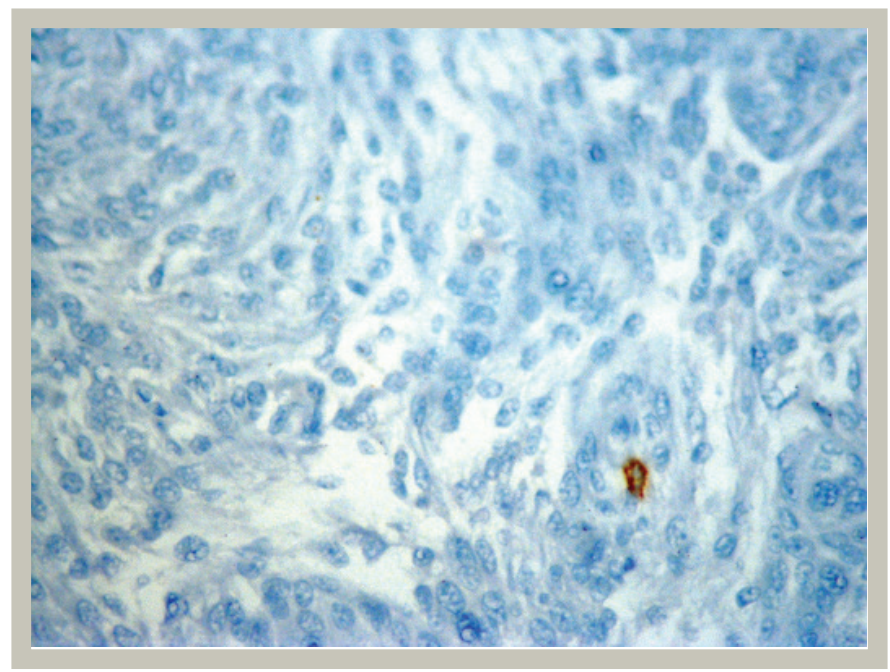

Figure 3A. TIM-3 grade 1, few sparse cell aggregates (TIM-3X400) TIM-3: T-cell immunoglobulin and mucin domain containing-3

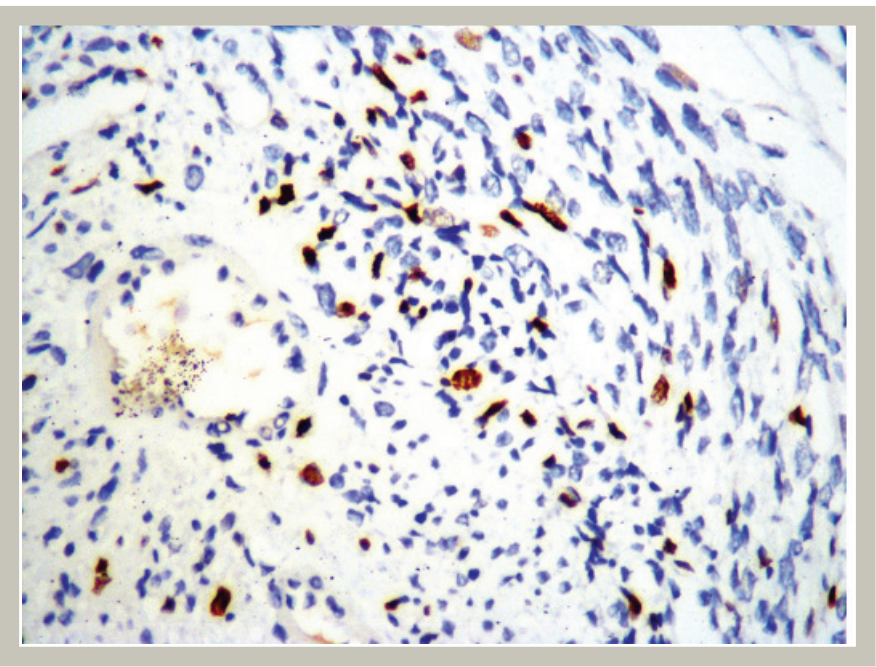

Figure 3B. Perivascular TIM-3 grade 3 in lymphocyte-rich meningioma tissue (TIM-3X400)

TIM-3: T-cell immunoglobulin and mucin domain containing-3 work has been conducted on therapies that target the ICM. The cell types from which the meningioma originates are different from other cancers; however, the mechanisms for the immune system response are similar. This mechanism is regulated by ICMs, such as LAG-3, TIM-3, and CD38 (11).

ICM regulates the immune system's response to various antigens. The T-cell response is inhibited or stimulated by these molecules (6). Cancer cells use this method to avoid the immune response and suppress the immune response by activating inhibitory ICMs. Therefore, suppression of these molecules can be used in cancer immunotherapy (7).

Some of the ICM molecules are LAG-3, TIM-3, and CD38 (7). No study in the literature has examined the relationship between meningiomas and these ICMs. However, few studies

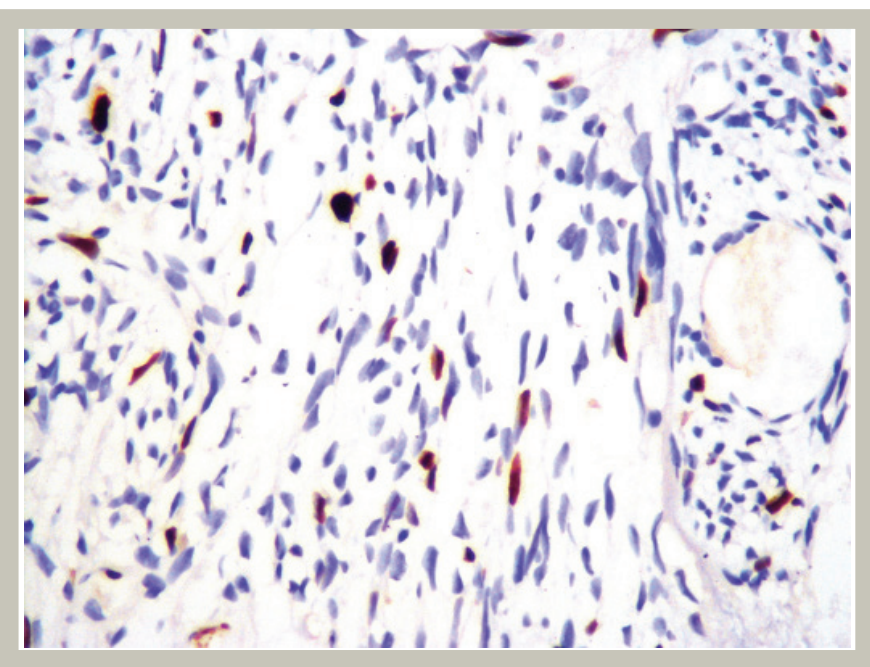

Figure 4A. CD38 grade 1 cells (CD38X400)

CD38: Cluster of differentiation 38

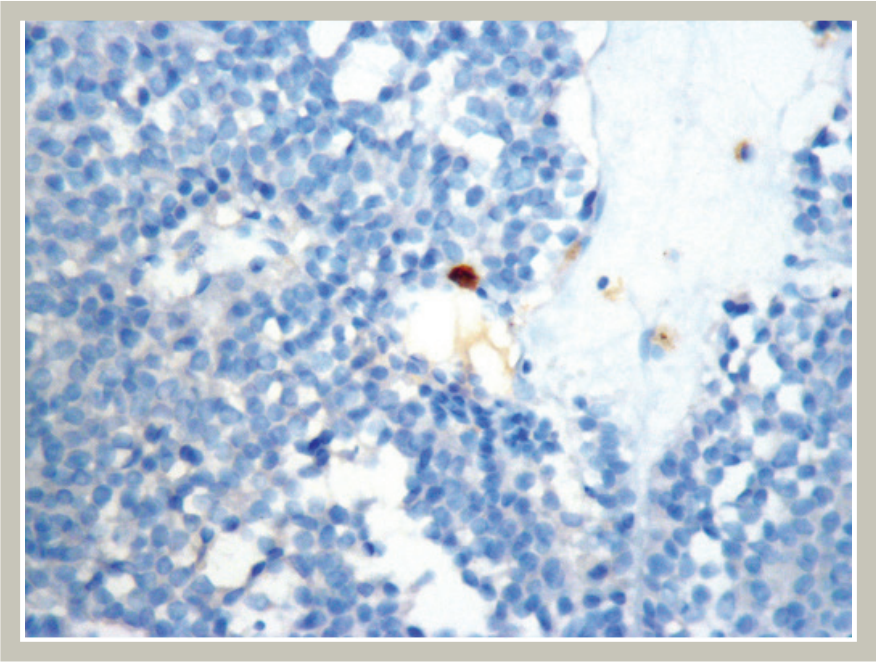

Figure 4B. CD38 grade 3 cells (CD38X400)

CD38: Cluster of differentiation 38 


\begin{tabular}{|c|c|c|c|c|}
\hline \multirow[t]{2}{*}{$n=25$} & \multicolumn{3}{|c|}{ LAG-3 } & \multirow[b]{2}{*}{$p$ value } \\
\hline & $\begin{array}{l}1 \\
n=10 \\
n(\%)\end{array}$ & $\begin{array}{l}2 \\
n=10 \\
n(\%)\end{array}$ & $\begin{array}{l}3 \\
n=5 \\
n(\%)\end{array}$ & \\
\hline \multicolumn{5}{|l|}{ Gender } \\
\hline Female & $8(80)$ & $7(70)$ & $4(80)$ & \multirow{2}{*}{0.85} \\
\hline Male & $2(20)$ & $3(30)$ & $1(20)$ & \\
\hline \multicolumn{5}{|l|}{ Localization } \\
\hline Frontal & $2(20)$ & $2(20)$ & $2(20)$ & \multirow{4}{*}{0.63} \\
\hline Occipital & $3(30)$ & $1(10)$ & $2(40)$ & \\
\hline Parietal & $2(20)$ & $3(30)$ & $1(20)$ & \\
\hline Temporal & $3(30)$ & $4(40)$ & - & \\
\hline \multicolumn{5}{|c|}{ Pathological subtype } \\
\hline Atypical & $1(10)$ & $1(10)$ & $2(40)$ & \multirow{5}{*}{0.5} \\
\hline Fibrosis & $3(30)$ & $2(20)$ & - & \\
\hline Transitional & $2(20)$ & $1(10)$ & $2(40)$ & \\
\hline Meningeal & $1(10)$ & $3(30)$ & - & \\
\hline Malignant & $3(30)$ & $3(30)$ & $1(20)$ & \\
\hline \multicolumn{5}{|l|}{ Size } \\
\hline $1(<3 \mathrm{~cm})$ & $10(100)$ & - & - & \multirow{3}{*}{$<0.001 *$} \\
\hline $2(3-6 \mathrm{~cm})$ & - & $8(80)$ & $1(20)$ & \\
\hline $3(>6 \mathrm{~cm})$ & - & $2(20)$ & $4(80)$ & \\
\hline \multicolumn{5}{|c|}{ Parenchymal invasion } \\
\hline None & $6(60)$ & $7(70)$ & $3(60)$ & \multirow{2}{*}{0.88} \\
\hline Yes & $4(40)$ & $3(30)$ & $2(40)$ & \\
\hline \multicolumn{5}{|l|}{ Bone invasion } \\
\hline None & $8(80)$ & $8(80)$ & $4(80)$ & \multirow{2}{*}{1} \\
\hline Yes & $2(20)$ & $2(20)$ & $1(20)$ & \\
\hline \multicolumn{5}{|c|}{ Degree of edema } \\
\hline 1- Minimal & $3(30)$ & $2(20)$ & - & \multirow{3}{*}{0.65} \\
\hline $\begin{array}{l}\text { 2- Smaller than } \\
\text { tumor size }\end{array}$ & $3(30)$ & $5(50)$ & $3(60)$ & \\
\hline $\begin{array}{l}\text { 3- More than } \\
\text { tumor size }\end{array}$ & $4(40)$ & $3(30)$ & $2(40)$ & \\
\hline $\begin{array}{l}{ }^{*} \text { The relationship } \\
(p<0.05) .{ }^{* *} \text { Chi-sq } \\
\text { between categorica } \\
\text { status and variable }\end{array}$ & $\begin{array}{l}\text { ten LAG-3 st } \\
\text { tablistics. Cons } \\
\text { G-3: Lympho }\end{array}$ & $\begin{array}{l}\text { s and siz } \\
\text { ere used } t \\
\text { ring the r } \\
\text { te activati }\end{array}$ & $\begin{array}{l}\text { statistica } \\
\text { aluate th } \\
\text { ionship b } \\
\text { gene-3 }\end{array}$ & $\begin{array}{l}\text { significant } \\
\text { lationship } \\
\text { veen } L A G-3\end{array}$ \\
\hline
\end{tabular}

have examined the relationship between Programmed death-ligand 1 (PDL1) and PDL2 of ICMs and meningiomas $(2,12,13,14)$. Han et al. (2) reported that as the grade of meningiomas increased, PDL1 levels also increased with a negative effect on survival. Wang et al. (14) revealed that immunotherapy is more effective if PDL1 is inhibited in neurofibromatosis-related meningiomas. Proctor et al. (12)

\begin{tabular}{|c|c|c|c|}
\hline \multirow[t]{2}{*}{$n=25$} & \multicolumn{2}{|c|}{ TIM-3 } & \multirow[b]{2}{*}{$p$ value } \\
\hline & $\begin{array}{l}1 \\
n=19 \\
n(\%)\end{array}$ & $\begin{array}{l}2 \\
n=6 \\
n(\%)\end{array}$ & \\
\hline \multicolumn{4}{|l|}{ Gender } \\
\hline Female & $14(73.7)$ & $5(83.3)$ & \multirow{2}{*}{0.63} \\
\hline Male & $5(26.3)$ & $1(16.7)$ & \\
\hline \multicolumn{4}{|l|}{ Localization } \\
\hline Frontal & $4(21.1)$ & $2(33.3)$ & \multirow{4}{*}{0.77} \\
\hline Occipital & $5(26.3)$ & $1(16.7)$ & \\
\hline Parietal & $4(21.1)$ & $2(33.3)$ & \\
\hline Temporal & $6(31.6)$ & $1(16.7)$ & \\
\hline \multicolumn{4}{|l|}{ Pathological subtype } \\
\hline Atypical & $4(21.1)$ & - & \multirow{5}{*}{0.72} \\
\hline Fibrosis & $4(21.1)$ & $1(16.7)$ & \\
\hline Transitional & $3(15.8)$ & $2(33.3)$ & \\
\hline Meningeal & $3(15.8)$ & $1(16.7)$ & \\
\hline Malignant & $5(26.3)$ & $2(33.3)$ & \\
\hline \multicolumn{4}{|l|}{ Size } \\
\hline $1(<3 \mathrm{~cm})$ & $9(47.4)$ & $1(16.7)$ & \multirow{3}{*}{0.19} \\
\hline $2(3-6 \mathrm{~cm})$ & 7 (36.8) & $2(33.3)$ & \\
\hline $3(>6 \mathrm{~cm})$ & $3(15.8)$ & $3(50)$ & \\
\hline \multicolumn{4}{|l|}{ Parenchymal invasion } \\
\hline None & $12(63.2)$ & $4(66.7)$ & \multirow{2}{*}{0.88} \\
\hline Yes & $7(36.8)$ & $2(33.3)$ & \\
\hline \multicolumn{4}{|l|}{ Bone invasion } \\
\hline None & $16(84.2)$ & $4(66.7)$ & \multirow{2}{*}{0.35} \\
\hline Yes & $3(15.8)$ & $2(33.3)$ & \\
\hline \multicolumn{4}{|l|}{ Degree of edema } \\
\hline 1- Minimal & $4(21.1)$ & $1(16.7)$ & \multirow{3}{*}{0.94} \\
\hline 2- Smaller than tumor size & $8(42.1)$ & $3(50)$ & \\
\hline 3- More than tumor size & $7(36.8)$ & $2(33.3)$ & \\
\hline \multicolumn{4}{|c|}{$\begin{array}{l}* * \text { Chi-square test statistics were used to evaluate the relationship between } \\
\text { categorical variables. Considering the relationship between TIM-3 Status } \\
\text { and variables, there was no statistical significance }(p>0.05) \text {. TIM-3: T-cell } \\
\text { immunoglobulin and mucin domain containing-3 }\end{array}$} \\
\hline
\end{tabular}

reported that PDL2 expression is higher in meningiomas compared to the normal cerebral cortex.

TIM-3 is a cell surface protein expressed from Th1 cells and suppresses the immune response by connecting to galectin- 9 in T-cells (15). Models with solid tumors, such as melanoma, breast cancer, and colon cancers, showed an increased programmed cell death protein 1 level, which is a sign of T-cell reduction in tumor-infiltrating cells. These findings suggest that TIM-3 suppresses tumor death through the immune 


\begin{tabular}{|c|c|c|c|c|}
\hline \multirow[t]{2}{*}{$n=25$} & \multicolumn{3}{|c|}{ CD38 } & \multirow{2}{*}{$p$ value } \\
\hline & $\begin{array}{l}1 \\
n=19 \\
n(\%)\end{array}$ & $\begin{array}{l}2 \\
n=5 \\
n(\%)\end{array}$ & $\begin{array}{l}3 \\
n=1 \\
n(\%)\end{array}$ & \\
\hline \multicolumn{5}{|l|}{ Gender } \\
\hline Female & $15(78.9)$ & $4(80)$ & - & \multirow{2}{*}{0.19} \\
\hline Male & $4(21.1)$ & $1(20)$ & $1(100)$ & \\
\hline \multicolumn{5}{|l|}{ Localization } \\
\hline Frontal & $5(26.3)$ & $1(20)$ & - & \multirow{4}{*}{0.48} \\
\hline Occipital & $6(31.6)$ & - & - & \\
\hline Parietal & $4(21.1)$ & $2(40)$ & - & \\
\hline Temporal & $4(21.1)$ & $2(40)$ & $1(100)$ & \\
\hline \multicolumn{5}{|c|}{ Pathological subtype } \\
\hline Atypical & $3(15.8)$ & $1(20)$ & - & \multirow{5}{*}{0.29} \\
\hline Fibrosis & $5(26.3)$ & - & - & \\
\hline Transitional & $4(21.1)$ & $1(20)$ & - & \\
\hline Meningeal & $3(15.8)$ & - & $1(100)$ & \\
\hline Malignant & $4(21.1)$ & $3(60)$ & - & \\
\hline \multicolumn{5}{|l|}{ Size } \\
\hline $1(<3 \mathrm{~cm})$ & $8(42.1)$ & $2(40)$ & - & \multirow{3}{*}{$0.04 *$} \\
\hline $2(3-6 \mathrm{~cm})$ & $9(47.4)$ & - & - & \\
\hline $3(>6 \mathrm{~cm})$ & $2(10.5)$ & $3(60)$ & $1(100)$ & \\
\hline \multicolumn{5}{|c|}{ Parenchymal invasion } \\
\hline None & $14(73.7)$ & $1(20)$ & $1(100)$ & \multirow{2}{*}{0.06} \\
\hline Yes & $5(26.3)$ & $4(80)$ & - & \\
\hline \multicolumn{5}{|l|}{ Bone invasion } \\
\hline None & $15(78.9)$ & $4(80)$ & $1(100)$ & \multirow{2}{*}{0.88} \\
\hline Yes & $4(21.1)$ & $1(20)$ & - & \\
\hline \multicolumn{5}{|c|}{ Degree of edema } \\
\hline 1- Minimal & $5(26.3)$ & - & - & \multirow{3}{*}{0.16} \\
\hline $\begin{array}{l}\text { 2- Smaller than } \\
\text { tumor size }\end{array}$ & $9(47.4)$ & $1(20)$ & $1(100)$ & \\
\hline $\begin{array}{l}\text { 3- More than } \\
\text { tumor size }\end{array}$ & $5(26.3)$ & $4(80)$ & - & \\
\hline \multicolumn{5}{|c|}{$\begin{array}{l}\text { **Chi-square test statistics were used to evaluate the relationship between } \\
\text { categorical variables. Considering the relationship between } L A G-3 \text { status and } \\
\text { variables, *The relationship between } L A G-3 \text { status and size is statistically } \\
\text { significant ( } p<0.05) \text {. CD38: Cluster of differentiation } 38, L A G-3: \text { Lymphocyte } \\
\text { activation gene-3 }\end{array}$} \\
\hline
\end{tabular}

system by causing T-cell depletion, and the tumor relieved of the immune system. Therefore, TIM-3 may be a potential immune marker for cancer treatment. Galectins are previously reported to be associated with poor prognosis and metastasis in many cancer types (16). Recent studies with galectin 9 have shown its role as the main T-cell activity regulator, and T-cell activation is suppressed with galectin 9 infusion $(17,18)$. Liu et al. (19) investigated the relationship of galectin 9 with the TIM-3 pathway and brain tumors. This study examined the lymphocytes in peripheral blood samples of patients with glioma and those normal and detected significantly increased galectin 9 and TIM-3 activity in the peripheral blood by TIL compared to the control group. No study has reported about TIM-3 level in meningiomas. Our study used IHC staining to evaluate TIM-3 expression in meningiomas and compared tumor histopathological grade, size, degree of edema, localization, parenchymal invasion, and bone invasion. No statistically significant difference was found between the TIM-3 level and these features. The small number of patients both prevented homogeneous distribution and affected the statistical results.

LAG-3 is also a membrane protein that is expressed on T-cells and inhibits T-cells by connecting to major histocompatibility complex class II receptors (20). Additionally, LAG-3 downregulates the immune system by regulating the regulatory T-cell functions (21). LAG-3 expression has been shown to increase tumor growth in many cancer types. Therefore, the LAG-3 protein in TILs is seen as a potential target in cancer therapy in the future (19). Our study evaluated LAG-3 expression in meningiomas using IHC staining and compared tumor histopathological grade, size, degree of edema, localization, parenchymal invasion, and bone invasion. No statistically significant difference was found between these features compared with the LAG-3 level, except for the tumor size. LAG-3 level was statistically higher in bigsized meningiomas.

CD38 is a type 2 membrane protein that regulates microglial activation $(22,23)$ and many functions such as calcium mechanism, autophagy, and tumorigenesis (24). It catalyzes the synthesis of cyclic adenosine diphosphate-ribose, which increases intracellular calcium and kills stimulated cells by activating microglial cells (24). The literature reports no study that investigated the relationship between meningiomas and CD38. However, a study that investigated the relationship between CD38 levels and gliomas was conducted by Blacher et al. (24) and reported that approximately 30\% of the glioma cell mass is formed by microglia and macrophage infiltration. In addition to its beneficial effects on microglial invasion, it also has harmful effects (24). Evidence showed that tumor-associated microglia and macrophages facilitate tumor invasion and progression $(25,26,27,28,29)$. Therefore, CD38 inhibition is thought to decelerate glioma progression. Blacher et al. (24) reported that rhein tri-potassium salt (K-rhein), which provides microglial inhibition due to CD38 
inhibition, slows glioblastoma progression. According to this, CD38 inhibition may reduce high-grade meningiomas, but the evidence is insufficient. Our study evaluated the CD38 expression in meningiomas using IHC staining and compared tumor histopathological grade, size, degree of edema, localization, parenchymal invasion, and bone invasion. No statistically significant difference was found between these features compared with CD38 level, except for the tumor size. CD38 level was statistically higher in big-sized meningiomas.

\section{Conclusion}

In conclusion, this study is the first to investigate LAG-3, TIM-3, and CD38 levels in meningiomas. Our study revealed a significant correlation between LAG-3 level and meningioma sizes. No significant correlation was found with other data. However, the number of patients in our study was insufficient. Therefore, larger patient groups may yield more significant results.

\section{Ethics}

Ethics Committee Approval: University of Health Sciences Turkey, Bakırköy Dr. Sadi Konuk Training and Research Hospital Local Ethics Committee, dated 08.01.2018 and numbered 2018-01-07.

Informed Consent: All patients signed informed consent.

Peer-review: Externally and internally peer-reviewed.

\section{Authorship Contributions}

Surgical and Medical Practices: O.T., Data Collection or Processing: O.H., Analysis or Interpretation: U.E., C.T., Literature Search: U.E., C.O., Ö.G., Writing: O.H.

Conflict of Interest: No conflict of interest was declared by the authors.

Financial Disclosure: The authors declared that this study received no financial support.

\section{REFERENCES}

1. Ostrom QT, Gittleman H, Liao P, et al. CBTRUS statistical report: primary brain and central nervous system tumors diagnosed in the United States in 2007-2011. Neuro Oncol 2014;16 Suppl (Suppl 4):iv1-63.

2. Han SJ, Reis G, Kohanbash G, et al. Expression and prognostic impact of immune modulatory molecule PD-L1 in meningioma. J Neurooncol 2016;130:543-552.

3. Rogers L, Barani I, Chamberlain M, et al. Meningiomas: knowledge base, treatment outcomes, and uncertainties. A RANO review. J Neurosurg 2015;122:4-23.

4. Jenkinson MD, Weber DC, Haylock BJ, Mallucci CL, Zakaria R, Javadpour M. Atypical meningoma: current management dilemmas and prospective clinical trials. J Neurooncol 2015;121:1-7.

5. Kaley T, Barani I, Chamberlain M, et al. Historical benchmarks for medical therapy trials in surgery- and radiation-refractory meningioma: a RANO review. Neuro Oncol 2014;16:829-840.

6. Zou W, Chen L. Inhibitory B7-family molecules in the tumour microenvironment. Nat Rev Immunol 2008;8:467-477.

7. Vesely MD, Kershaw MH, Schreiber RD, Smyth MJ. Natural innate and adaptive immunity to cancer. Annu Rev Immunol 2011;29:235-271.

8. Magill ST, Young JS, Chae R, Aghi MK, Theodosopoulos PV, McDermott MW. Relationship between tumor location, size, and WHO grade in meningioma. Neurosurg Focus 2018;44:E4.

9. Wang $\mathrm{H}$, Mao L, Zhang $\mathrm{T}$, et al. Altered expression of TIM-3, LAG3, IDO, PD-L1, and CTLA-4 during nimotuzumab therapy correlates with responses and prognosis of oral squamous cell carcinoma patients. J Oral Pathol Med 2019;48:669-676.
10. Norman G. Likert scales, levels of measurement and the "laws" of statistics. Adv Health Sci Educ Theory Pract 2010;15:625-632.

11. Han L, Liu C, Qi H, et al. Systemic delivery of monoclonal antibodies to the central nervous system for brain tumor therapy. Adv Mater 2019;31:e1805697.

12. Proctor DT, Patel Z, Lama S, Resch L, van Marle G, Sutherland GR. Identification of PD-L2, B7-H3 and CTLA-4 immune checkpoint proteins in genetic subtypes of meningioma. Oncoimmunology 2018;8:e1512943.

13. Bi WL, Wu WW, Santagata S, Reardon DA, Dunn IF. Checkpoint inhibition in meningiomas. Immunotherapy 2016;8:721-731.

14. Wang S, Liechty B, Patel $S$, et al. Programmed death ligand 1 expression and tumor infiltrating lymphocytes in neurofibromatosis type 1 and 2 associated tumors. J Neurooncol 2018;138:183-190.

15. Monney L, Sabatos CA, Gaglia JL, et al. Th1-specific cell surface protein Tim-3 regulates macrophage activation and severity of an autoimmune disease. Nature 2002;415:536-541.

16. Liu FT, Rabinovich GA. Galectins: regulators of acute and chronic inflammation. Ann N Y Acad Sci 2010;1183:158-182.

17. Seki M, Oomizu S, Sakata KM, et al. Galectin-9 suppresses the generation of Th17, promotes the induction of regulatory $T$ cells, and regulates experimental autoimmune arthritis. Clin Immunol 2008;127:78-88.

18. Veenstra RG, Taylor PA, Zhou Q, et al. Contrasting acute graftversus-host disease effects of Tim-3/galectin-9 pathway blockade dependent upon the presence of donor regulatory T cells. Blood 2012;120:682-690. 
19. Liu Z, Han H, He X, et al. Expression of the galectin-9-Tim-3 pathway in glioma tissues is associated with the clinical manifestations of glioma. Oncol Lett 2016;11:1829-1834.

20. Huard B, Tournier M, Hercend T, Triebel F, Faure F. Lymphocyteactivation gene 3/major histocompatibility complex class II interaction modulates the antigenic response of CD4+ T Iymphocytes. Eur J Immunol 1994;24:3216-3221.

21. Huang CT, Workman CJ, Flies D, et al. Role of LAG-3 in regulatory $T$ cells. Immunity 2004;21:503-513.

22. Krex D, Klink B, Hartmann C, et al. Long-term survival with glioblastoma multiforme. Brain 2007;130:2596-2606.

23. Rivest S. Regulation of innate immune responses in the brain. Nat Rev Immunol 2009;9:429-439.

24. Blacher E, Ben Baruch B, Levy A, et al. Inhibition of glioma progression by a newly discovered CD38 inhibitor. Int J Cancer 2015;136:1422-1433.
25. Charles NA, Holland EC, Gilbertson R, Glass R, Kettenmann H. The brain tumor microenvironment. Glia 2011;59:1169-1180. Corrected and republished in: Glia 2012;60:502-514.

26. Badie B, Schartner J. Role of microglia in glioma biology. Microsc Res Tech 2001;54:106-113.

27. Watters JJ, Schartner JM, Badie B. Microglia function in brain tumors. J Neurosci Res 2005;81:447-455.

28. Yang I, Han SJ, Kaur G, Crane C, Parsa AT. The role of microglia in central nervous system immunity and glioma immunology. J Clin Neurosci 2010;17:6-10.

29. Markovic DS, Vinnakota K, Chirasani S, et al. Gliomas induce and exploit microglial MT1-MMP expression for tumor expansion. Proc Natl Acad Sci USA 2009 Jul;106:12530-12535. 